\title{
PENGAMBILAN KEPUTUSAN INVESTASI SAHAM MENGGUNAKAN PENDEKATAN PRICE EARNING RATIO (STUDI KASUS PADA PERUSAHAAN TERDAFTAR DI INDEKS SRI-KEHATI \\ PERIODE 2015 - 2017)
}

\author{
Akbar Ilham Nursetyo, Akhmad Syarifudin \\ Sekolah Tinggi Ilmu Ekonomi Putra Bangsa
}

email: akbarilhamn@gmail.com

\begin{abstract}
Abstrak
Nilai intrinsik merupakan nilai seharusnya dari suatu saham. Terdapat tiga kondisi pada penghitungan nilai intrinsik saham yaitu undervalue dimana nilai intrinsik lebih besar dari harga pasar, overvalue dimana nilai intrinsik lebih kecil dari harga pasar, sedangkan correct value dimana nilai intrinsik sama dengan harga pasar. Tujuan penelitian ini untuk mengetahui nilai intrinsik dalam menyusun strategi dan membuat keputusan bagi investor dalam menentukan waktu yang tepat saat investasi saham, baik menjual, membeli atau menahan saham tersebut. Analisis yang digunakan dalam menghitung nilai intrinsik saham dalam penelitian ini menggunakan analisis fundamental dengan pendekatan Price Earning Ratio. Objek penelitian ini menggunakan perusahaan yang terdaftar pada Indeks SRI-KEHATI periode 2015-2017. Hasil penelitian menunjukkan 10 saham perusahaan dalam kondisi undervalue yaitu perusahaan BBNI, BMRI, INDF, JSMR, KLBF, LSIP, PJAA, TLKM, UNTR, WSKT maka keputusan investasi yang tepat adalah membeli saham tersebut. Terdapat 5 perusahaan yang sahamnya dalam kondisi overvalue yaitu ASII, BBCA, BBRI, BDMN, UNVR dan WIKA maka keputusan investasi yang tepat yaitu menjual saham apabila telah memilikinya atau tidak membeli saham tersebut. Tidak terdapat saham perusahaan pada Indeks SRI-KEHATI dengan kondisi correct value.
\end{abstract}

Kata Kunci: Analisis Fundamental, Nilai Intrinsik, Price Earning Ratio

\section{ABSTRACT}

Intrinsic value is the fair value of a stock. There are three conditions in calculating the intrinsic value of a stock that is undervalue where intrinsic value is greater than market price, overvalue where intrinsic value is smaller than market price, and correct value where intrinsic value is equal to market price. The purpose of this research was to find out the intrinsic value of developing strategies and making decisions for investors in determining the right time when stock investment, whether selling, buying or hold the stock. The analysis used in calculating the intrinsic value of stock in this research using fundamental analysis with the Price Earning Ratio method. The object of this research was companies listed on the SRI-KEHATI Index for the period 2015-2017. The results showed that 10 company stocks were undervalue BBNI, BMRI, INDF, JSMR, KLBF, LSIP, PJAA, TLKM, UNTR, WSKT. The right investment decision was to buying the stock. There were 5 companies whose stock were in overvalue conditions, ASII, BBCA, BBRI, BMRI, UNVR, WIKA. The right investment decision to sold the stock if they already have, or not bought it. There were no company stock in the SRI-KEHATI Index with the correct value condition.

Keywords: Fundamental Analysis, Intrinsic Value, Price Earning Ratio

\section{PENDAHULUAN}

Investasi pada hakekatnya merupakan penempatan sejumlah dana pada saat ini dengan harapan untuk memperoleh keuntungan di masa mendatang. Umumnya investasi dibedakan menjadi dua, yaitu investasi pada financial assets dan investasi pada real assets. Investasi pada financial assets dilakukan di pasar uang dan pasar modal. Investasi pada financial assets yang dilakukan pada pasar uang, misalnya berupa sertifikat deposito, commercial paper, surat berharga pasar uang, dan lainnya. Sedangkan pada pasar modal, misalnya berupa saham, obligasi, waran, opsi, dan lainnya. Investasi pada real assets diwujudkan dalam bentuk pembelian aset produktif, pendirian pabrik, pembukaan pertambangan, pembukaan perkebunan dan lainnya (Halim,2015:1).

Salah satu jenis investasi yang dapat digunakan untuk memperoleh keuntungan dimasa yang akan datang 


\section{PENGAMBILAN KEPUTUSAN INVESTASI SAHAM MENGGUNAKAN PENDEKATAN PRICE EARNING RATIO (STUDI KASUS PADA PERUSAHAAN TERDAFTAR DI INDEKS SRI-KEHATI \\ PERIODE 2015 - 2017)}

adalah investasi pada pasar modal. Pasar modal merupakan sarana yang digunakan oleh para pelaku usaha dalam memperoleh dana untuk melakukan ekspansi pada perusahaannya yang diperoleh dari investor yang memiliki dana lebih di mana investor tersebut masuk ke dalam pasar modal untuk memperoleh keuntungan dari dana yang telah di investasikan sehingga dapat menimbulkan timbal balik yang positif antara pelaku usaha dengan para investor.

Pasar modal memiliki peran besar bagi perekonomian suatu negara karena pasar modal menjalankan dua fungsi sekaligus yaitu fungsi ekonomi dan fungsi keuangan. Keberadaan pasar modal diharapkan aktivitas perekonomian menjadi meningkat, karena pasar modal merupakan alternatif pendanaan bagi perusahaan sehingga perusahaan dapat beroperasi dengan skala besar, pada gilirannya akan meningkatkan profitabilitas perusahaan dan kemakmuran masyarakat luas (Halim, 2015:2).

Saham dikenal dengan karakteristik high risk-high return yang berarti saham merupakan surat berharga dengan risiko tinggi tetapi juga memberikan peluang keuntungan yang tinggi pula. Saham memungkinkan investor mendapatkan dividen (return) dan keuntungan (capital gain) dalam jumlah yang besar dan dalam waktu yang singkat. Namun, saham juga merupakan sekuritas yang sangat rentan mengalami fluktuasi harga yang dapat membuat investor mengalami kerugian dalam waktu singkat.

Secara fundamental harga suatu jenis saham dipengaruhi oleh ekspektasi kinerja perusahaan dan kemungkinan risiko yang dihadapi perusahaan. Kinerja perusahaan tercermin dari laba operasional dan laba bersih per unit saham serta beberapa rasio keuangan yang dapat menggambarkan kekuatan manajemen dalam mengelola perusahaan. Risiko perusahaan tercermin dari daya tahan perusahaan dalam menghadapi siklus ekonomi maupun faktor makroekonomi dan makro nonekonomi. Dengan kata lain kinerja perusahaan dan risiko yang dihadapi dipengaruhi oleh faktor makroekonomi dan mikroekonomi. Data keuangan masa lalu serta faktor makro dan mikro bisa dipakai untuk memprediksi kinerja perusahaan di masa datang (Samsul, 2015:210)

SRI-KEHATI merupakan indeks saham yang terbentuk antara kerjasama Bursa Efek Indonesia (BEI) dengan Yayasan Keanekaragaman Hayati. SRI adalah kependekan dari Sustainable Responsible Investment. Indeks ini diharapkan memberi tambahan informasi kepada investor yang ingin berinvestasi pada emiten emiten yang memiliki kinerja yang sangat baik dalam mendorong usaha berkelanjutan, serta memiliki kesadaran terhadap lingkungan dan menjalankan tata kelola perusahaan yang baik. Indeks ini terdiri dari 25 saham perusahaan tercatat yang dipilih dengan mempertimbangkan kriteria-kriteria tertentu seperti total aset, Price Earning Ratio (PER), dan free float (Bursa Efek Indonesia:2018).

Return merupakan salah satu faktor yang dapat menarik minat investor untuk kegiatan investasi dalam menanamkan modalnya pada saham perusahaan. Selama tahun 2015-2017, indeks SRI-KEHATI memiliki return tertinggi dibandingkan dengan indeks lain. Return yang tinggi dapat menyebabkan menarik minat investor kedepannya untuk melakukan kegiatan investasi pada saham perusahaan yang terdaftar di indeks yang memiliki return tinggi.

Tabel 1 Perbandingan Return

\begin{tabular}{lcccc}
\hline & \multicolumn{4}{c}{ Return (\%) } \\
\cline { 2 - 5 } Indeks Saham & 2015 & 2016 & 2017 & $\begin{array}{c}\text { Rata- } \\
\text { rata }\end{array}$ \\
\hline $\begin{array}{l}\text { SRI-KEHATI } \\
\text { Bisnis27 }\end{array}$ & $-11,44$ & 14,25 & 25,40 & 9,40 \\
$\begin{array}{l}\text { Indeks Harga } \\
\text { Saham }\end{array}$ & $-12,54$ & 15,50 & 24,21 & 9,05 \\
$\begin{array}{l}\text { Gabungan } \\
\text { (IHSG) }\end{array}$ & $-12,90$ & 14,26 & 20,81 & 7,39 \\
$\begin{array}{l}\text { LQ-45 } \\
\text { Kompas 100 }\end{array}$ & $-12,20$ & 10,77 & 21,22 & 6,60 \\
Jakarta & $-14,17$ & 12,34 & 19,59 & 5,92 \\
$\begin{array}{l}\text { Islamic Index } \\
\text { (JII) }\end{array}$ & 13,31 & 9,98 & 2,99 \\
PEFINDO25 & $-29,13$ & 16,19 & $-8,31$ & $-7,08$ \\
\hline
\end{tabular}

Sumber : data diolah investing.com:2018

Kemampuan menganalisis laporan keuangan perusahaan dan kinerja investasi merupakan syarat mutlak bagi investor yang ingin memaksimalkan keputusan investasinya dan untuk mengurangi risiko dalam berinvestasi. Menurut Rahardjo (2006:105) dalam Wulandari et al (2015:74), setiap investor wajib menguasai informasi laporan keuangan dari suatu emiten bila ingin sukses membuat keputusan investasi yang akurat sehingga bisa memberikan keuntungan maksimal. Kondisi fundamental perusahaan yang baik dapat dijadikan acuan oleh para investor untuk memilih saham perusahaan tersebut untuk dijadikan pilihan investasi Dalam melakukan penilaian saham dengan menggunakan analisis laporan keuangan dapat digunakan teknik analisis rasio.

Variabel-variabel atau rasio-rasio keuangan yang digunakan untuk melakukan analisis penilaian saham yaitu ROE (Return On Equity), EPS (Earnings Per Share), DPS (Dividend Per Share), DPR (Dividend Payout Ratio), dan PER (Price Earnings Ratio). Penilaian terhadap rasio-rasio ini dapat dilihat dari perkembangan masing - masing secara time series atau dari periode satu ke periode lainnya. Setelah mengetahui kondisi perusahaan yang dilihat dari perkembangan fundamental perusahaan, selanjutnya para investor atau analis harus melakukan analisis saham untuk mengetahui nilai sesungguhnya atau nilai intrinsik dari saham perusahaan. Setelah mengetahui nilai sesungguhnya atau nilai intrinsik para investor atau analis dapat membandingkan nilai intrinsik tersebut dengan harga pasarnya (Wulandari et al,2015:74).

Sebelum para investor mengambil keputusan investasi, investor perlu menganalisis nilai saham terlebih dahulu. Analisis nilai saham secara umum terbagi menjadi dua, yaitu analisis teknikal dan analisis fundamental. Analisis teknikal merupakan analisis pasar sekuritas yang memusatkan perhatian pada indeks saham, statistik atau harga pasar, sedangkan analisis fundamental mempelajari 


\section{PENGAMBILAN KEPUTUSAN INVESTASI SAHAM MENGGUNAKAN PENDEKATAN PRICE EARNING RATIO (STUDI KASUS PADA PERUSAHAAN TERDAFTAR DI INDEKS SRI-KEHATI \\ PERIODE 2015 - 2017)}

data - data fundamental seperti data keuangan perusahaan. Analisis fundamental memiliki dua jenis pendekatan, pendekatan present value dan pendekatan Price Earning Ratio (PER). Pendekatan yang digunakan dalam penelitian ini yaitu pendekatan PER. PER merupakan sebuah rasio yang menunjukkan hubungan antara harga pasar saham biasa dengan Earning Per Share (EPS). Penghitungan PER dilakukan dengan cara mencari nilai intrinsik saham kemudian membandingkan dengan harga pasar saham, sehingga dapat diketahui kondisi perusahaan apakah mengalami overvalued, correctly valued, atau undervalued (Aganta et al, 2015:2).

Berdasarkan hal-hal yang telah dikemukakan diatas, maka penulis tertarik untuk mengadakan penelitian untuk mengetahui bagaimana pengambilan keputusan investasi dengan menilai harga intrinsik saham perusahaan menggunakan pendekatan Price Earnings Ratio. Penelitian ini diberi judul "Pengambilan Keputusan Investasi Saham Menggunakan Pendekatan Price Earning Ratio Studi Kasus Perusahaan Terdaftar Pada Indeks SRI-KEHATI Periode 2015 - 2017”.

\section{LANDASAN TEORI}

\section{Investasi}

Menurut Halim (2015:13) investasi pada hakekatnya merupakan penempatan sejumlah dana pada saat ini dengan harapan untuk memperoleh keuntungan di masa mendatang. Sedangkan menurut Tandellilin (2010:2) Investasi merupakan komitmen untuk mengorbankan konsumsi sekarang (sacrifice current consumption) dengan memperbesar konsumsi di masa datang. Investasi dapat berkaitan dengan penanaman sejumlah dana pada aset riil seperti tanah, emas, rumah dan aset riil lainnya atau pada aset finansial seperti deposito, saham, obligasi, dan surat berharga lainnya.

\section{Pasar Modal}

Pasar modal (capital market) adalah pasar yang mempertemukan pihak yang menawarkan dan memerlukan dana jangka panjang, seperti saham dan obligasi (Halim, 2015:1). Sedangkan menurut Tandelilin (2010:26) pasar modal adalah pasar pertemuan antara pihak yang memiliki kelebihan dana dengan pihak yang membutuhkan dana dengan cara memperjualbelikan sekuritas yang umumnya memiliki umur lebih dari satu tahun, seperti saham dan obligasi. Sedangkan tempat dimana terjadinya jual beli sekuritas disebut bursa efek, oleh karena itu bursa efek adalah arti dasar pasar modal secara fisik.

Saham

Saham merupakan surat bukti kepemilikan atas asetaset perusahaan yang menerbitkan saham dengan memiliki saham suatu perusahaan, investor akan mempunyai hak terhadap pendapatan dan kekayaan perusahaan setelah dikurangi dengan pembayaran semua kewajiban perusahaan (Tandelilin, 2010:81). Saham menurut Halim (2015:6) adalah sebagai tanda penyertaan atau pemilikan seseorang atau badan dalam suatu perusahaan. Jadi saham merupakan surat berharga sebagai tanda bukti kepemilikan seseorang terhadap suatu perusahaan. Saham menarik bagi investor karena adanya keuntungan yang dinikmati pemegang saham.

\section{SRI-KEHATI}

Menurut Kehati (2018), indeks saham Sustainable and Responsible Investment (SRI)-KEHATI merupakan salah satu indeks yang menjadi indikator pergerakan harga saham di Bursa Efek Indonesia (BEI), yang menggunakan prinsip keberlanjutan, keuangan, dan tata kelola yang baik, serta kepedulian terhadap lingkungan hidup sebagai tolok ukurnya. Indeks ini diluncurkan pada 8 Juni 2009 oleh Yayasan Keanekaragaman Hayati Indonesia (KEHATI) bekerja sama dengan PT BEI.

Indeks SRI-KEHATI merupakan benchmark investasi bagi para investor ataupun manajer investasi dalam menentukan perusahaan publik mana yang memiliki kinerja baik dalam menjalankan usahanya dari sisi tata kelola finansial, sosial, dan lingkungan secara berkelanjutan.

Terdapat 25 emiten yang menjadi konstituen indeks SRI-KEHATI, yang diseleksi setiap dua periode dalam setahun, yaitu pada bulan April dan Oktober. Setelah terpilih, nama-nama dari 25 emiten tersebut akan dipublikasikan oleh BEI yang dapat dilihat $\mathrm{di}$ www.idx.co.id.

\section{Pendekatan Price Earning Ratio}

Menurut Tandelilin (2010:303), berdasarkan analisis fundamental terdapat pendekatan dalam menentukan nilai intrinsik saham. Pendekatan tersebut adalah pendekatan rasio harga terhadap earning (price earning ratio/PER). Pendekatan PER dalam penentuan nilai suatu saham dilakukan dengan menghitung berapa rupiah uang yang diinvestasikan ke dalam suatu saham untuk memperoleh satu rupiah pendapatan (earning) dari saham tersebut.

Pendekatan ini merupakan pendekatan yang lebih populer dipakai di kalangan analisis saham dan para praktisi. Dalam pendekatan PER atau disebut juga pendekatan multiplier, investor akan menghitung berapa kali (multiplier) nilai earning yang tercermin dalam harga suatu saham. Dengan kata lain, PER menggambarkan rasio atau perbandingan antara harga saham terhadap earning perusahaan. (Tandelilin,2010:320).

\section{Penilaian Saham}

Dalam melakukan transaksi di pasar modal khususnya saham, hal yang sangat penting untuk diperhatikan bagi seorang investor adalah penilaian harga saham selain kondisi perekonomian dan emiten. Dalam penilaian saham dikenal dengan adanya tiga jenis nilai, yaitu nilai buku, harga pasar, dan nilai intrinsik.Dalam melakukan analisis penilaian harga saham, terdapat dua jenis analisis yang dapat dilakukan oleh investor sebagai pertimbangan dalam keputusan investasi saham, yaitu :

\section{Analisis Teknikal}

Menurut Halim (2015:115) analisis ini dimulai dengan cara memperhatikan perubahan saham itu sendiri dari waktu ke waktu. Analisis ini beranggapan bahwa harga suatu saham akan ditentukan oleh supply and demand terhadap saham tersebut.

2. Analisis Fundamental

Menurut Hermuningsih (2012:194-197), salah satu aspek penting dari analisis fundamental adalah 


\section{PENGAMBILAN KEPUTUSAN INVESTASI SAHAM MENGGUNAKAN PENDEKATAN PRICE EARNING RATIO (STUDI KASUS PADA PERUSAHAAN TERDAFTAR DI INDEKS SRI-KEHATI \\ PERIODE 2015 - 2017)}

analisis laporan keuangan, karena dari situ dapat diperkirakan keadaan, atau posisi dan arah perusahaan. Berikut adalah beberapa jenis rasio laporan keuangan yang digunakan sebagai alat analisis keadaan keuangan dan kemampuan perusahaan yaitu dalam pendekatan Price Earning Ratio:
a. Return on Equity (ROE)
b. Earning per Share (EPS)
c. Dividend per Share (DPS)
d. Dividend Payout Ratio (DPR)
e. Price Earning Ratio (PER)

Pengambilan Keputusan Investasi

Secara umum keputusan membeli atau menjual saham ditentukan oleh perbandingan antara nilai intrinsik dengan harga pasarnya, dengan kriteria sebagai berikut (Halim, 2015:117-118) :

1. Jika harga pasar saham lebih kecil dari nilai intrinsiknya, maka saham tersebut sebaiknya dibeli dan ditahan sementara dengan tujuan untuk memperoleh capital gain jika kemudian harganya kembali naik.

2. Jika harga pasar saham sama dengan nilai intrinsiknya, maka jangan melakukan transaksi. Karena saham tersebut dalam keadaan keseimbangan, sehingga tidak ada keuntungan yang diperoleh dari transaksi pembelian atau penjualan saham tersebut.

3. Jika harga pasar saham lebih besar dari nilai intrinsiknya, maka saham tersebut sebaiknya dijual untuk menghindari kerugian. Karena tentu harganya kemudian akan turun dengan nilainya.

\section{METODE}

\section{Jenis Penelitian}

Jenis penelitian deskriptif melalui pendekatan kuantitatif. Penelitian ini bertujuan untuk memaparkan gambaran mengenai penilaian harga saham melalui datadata keuangan perusahaan yang tergabung dalam indeks SRI-KEHATI pada BEI dengan pendekatan PER dalam kaitannya dengan keputusan investasi.

\section{Objek dan Subjek Penelitian}

Objek penelitian yang diteliti oleh penulis merupakan perhitungan dalam penghitungan nilai intrinsik saham yaitu pada rasio - rasio laporan keuangan perusahaan yang tercatat di indeks SRI-KEHATI. Subjek penelitian ini merupakan perusahaan yang tercatat pada indeks SRIKEHATI dari periode 2015 - 2017.

\section{Populasi dan Sampel}

Populasi adalah wilayah generalisasi yang terdiri atas obyek/subyek yang mepunyai kualitas dan karakteristik sesuatu yang ditetapkan oleh peneliti untuk dipelajari dan kemudian ditarik kesimpulan (Sugiyono, 2010:115). Populasi dalam penelitian ini adalah seluruh perusahaan yang terdaftar pada indeks SRI-KEHATI selama 20152017, yaitu ada 28 perusahaan.

Sampel adalah bagian dari jumlah dan karakteristik yang dimiliki oleh populasi tersebut. Pemilihan sampel dalam penelitian ini menggunakan teknik purposive sampling yaitu teknik pengambilan sampel dengan pertimbangan atau kriteria tertentu (Sugiyono,2010:116) Adapun kriteria-kriteria yang ditentukan sebagai berikut :

1. Perusahaan yang terdaftar pada Indeks SRI-KEHATI dari tahun 2015-2017.

2. Perusahaan tersebut terdaftar secara konsisten pada Indeks SRI-KEHATI selama 2015-2017.

3. Perusahaan tersebut secara konsisten membagikan dividen selama 2015-2017.

Setelah populasi disesuaikan dengan kriteria tersebut jumlah populasi yang dapat digunakan menjadi sampel pada penelitian ini berjumlah 15 saham perusahaan.

\section{Metode Pengumpulan Data}

Metode pengumpulan data merupakan metode atau cara yang digunakan untuk memperoleh data yang diperlukan bagi suatu penelitian. Metode pengumpulan data yang digunakan dalam penelitian ini adalah metode dokumentasi yaitu pengumpulan data sekunder dari:

1. Laporan keuangan yang diperoleh dari www.idx.co.id dan stockbit.

2. Harga penutupan saham perusahaan yang terdaftar pada indeks SRI-KEHATI yang diperoleh dari website Yahoo Finance, investing.

\section{Metode Analisis Data}

Analisis data menggunakan aplikasi microsoft excel. Langkah-langkah yang harus dilakukan untuk menilai harga saham dengan metode pendekatan PER yaitu :

1. Melihat perkembangan kondisi keuangan perusahaan dengan analisis fundamental internal meliputi (Hermuningsih,2012:194-197):

a. Return on Equity (ROE)

$$
\mathrm{ROE}=\frac{\text { Laba Bersih }}{\text { Nilai Buku Ekuitas }}
$$

b. Earning per Share (EPS)

$$
\text { EPS }=\frac{\text { Laba Bersih }}{\text { Jumlah saham yang beredar }}
$$

c. Dividend per Share (DPS)

$$
\text { DPS }=\frac{\text { Dividend paid }}{\text { Jumlah saham yang beredar }}
$$

d. Dividend Payout Ratio (DPR)

$\mathrm{DPR}=\frac{\text { Dividend } \text { per lembar saham }}{\text { Jumlah saham yang beredar }}$

e. Price Earning Ratio (PER)

$$
\text { PER }=\frac{\text { Harga per lembar saham }}{\text { EPS }}
$$

2. Menentukan nilai intrinsik saham dengan menggunakan pendekatan PER

a. Menghitung expected earning growth rate

$\mathrm{g}=\mathrm{ROE} \times \mathrm{b}$

dimana

$\mathrm{b}=1-\mathrm{DPR}$

Tandelilin (2010:376)

b. Menghitung estimasi earning per share

$\mathrm{E}_{1}=\mathrm{EP}_{0}(1+\mathrm{g})$

Tambunan (2007:249)

c. Menghitung estimasi dividend per share

$\mathrm{D}_{1}=\mathrm{D}_{0}(1+\mathrm{g})$

Jones (2009:214)

d. Menentukan tingkat estimasi tingkat pengembalian yang diharapkan

$\mathrm{k}=\frac{\mathrm{D}_{1}}{\mathrm{P}_{0}}+\mathrm{g}$

Brigham dan Houston (2012:366) 
PENGAMBILAN KEPUTUSAN INVESTASI SAHAM MENGGUNAKAN PENDEKATAN PRICE EARNING RATIO (STUDI KASUS PADA PERUSAHAAN TERDAFTAR DI INDEKS SRI-KEHATI

PERIODE 2015 - 2017)

e. Menghitung estimasi price earning ratio $\operatorname{PER}=\frac{\mathrm{D}_{1} / \mathrm{E}_{1}}{\mathrm{k}-\mathrm{g}}$

Tandelilin (2010:376)

f. Menghitung nilai intrinsik

Nilai instrinsik $=$ Etimasi EPS $x$ PER

Tandelilin (2010:377)

$$
=\mathrm{E} 1 \times \mathrm{PER}
$$

3. Pengambilan keputusan investasi

a. Menilai perkembangan kondisi keuangan perusahaan dengan analisis fundamental internal yaitu Return On Equity, Dividend Payout Ratio, Dividend Per Share, Earning Per Share, Price Earning Ratio.

b. Menentukan nilai intrinsik atau kewajaran harga saham dengan membuat perbandingan antara nilai pasar (close price) dengan nilai intrinsik sebelum investor mengambil keputusan.

c. Menentukan keputusan investasi yang dapat diambil dengan mengetahui kondisi perusahaan yang telah dibandingkan.

\section{HASIL DAN PEMBAHASAN}

Tabel 2. Perkembangan ROE

\begin{tabular}{clrrrrr}
\hline & \multirow{2}{*}{ Kode } & \multicolumn{5}{c}{ Return on Equity(\%) } \\
\cline { 3 - 7 } & Saham & 2017 & 2016 & 2015 & Jumlah & $\begin{array}{c}\text { Rata- } \\
\text { rata }\end{array}$ \\
\hline 1 & ASII & 14,82 & 13,08 & 12,34 & 40,24 & 13,41 \\
2 & BBCA & 17,75 & 18,30 & 20,12 & 56,17 & 18,72 \\
3 & BBNI & 13,65 & 12,78 & 11,65 & 38,08 & 12,69 \\
4 & BBRI & 17,36 & 17,86 & 22,46 & 57,68 & 19,23 \\
5 & BMRI & 12,61 & 9,55 & 17,70 & 39,86 & 13,29 \\
6 & INDF & 11,00 & 11,99 & 8,60 & 31,59 & 10,53 \\
7 & JSMR & 11,40 & 11,04 & 10,67 & 33,11 & 11,04 \\
8 & KLBF & 17,66 & 18,86 & 18,81 & 55,33 & 18,44 \\
9 & LSIP & 9,40 & 7,75 & 8,49 & 25,64 & 8,55 \\
10 & PJAA & 11,26 & 8,42 & 16,18 & 35,86 & 11,95 \\
11 & TLKM & 29,16 & 27,64 & 29,16 & 85,96 & 28,65 \\
12 & UNTR & 16,14 & 11,98 & 7,11 & 35,23 & 11,74 \\
13 & UNVR & 135,40 & 135,85 & 121,22 & 392,47 & 130,82 \\
14 & WIKA & 9,27 & 9,51 & 12,93 & 31,71 & 10,57 \\
15 & WSKT & 18,46 & 10,81 & 10,80 & 40,07 & 13,36 \\
\hline
\end{tabular}

Terdapat lima perusahaan yang mengalami peningkatan secara konsisten setiap tahun yaitu ASII, BBNI, JSMR, UNTR dan WSKT. Terdapat tiga perusahaan yang mengalami penurunan konstan setiap tahunnya yaitu pada perusahaan BBCA, BBRI, WIKA. Rata-rata return on equity tertinggi selama tahun 20152017 diperoleh oleh UNVR, sementara rata-rata terendah diperoleh oleh perusahaan LSIP.

Tabel 3. Perkembangan DPR

\begin{tabular}{clrrrrr}
\hline \multirow{2}{*}{ No } & \multirow{2}{*}{$\begin{array}{c}\text { Kode } \\
\text { Saham }\end{array}$} & 2017 & 2016 & 2015 & Jumlah & $\begin{array}{c}\text { Rata- } \\
\text { rata }\end{array}$ \\
\cline { 3 - 7 } & & & & & & \\
\hline 1 & ASII & 39,67 & 44,87 & 49,54 & 134,08 & 44,69 \\
2 & BBCA & 26,97 & 8,38 & 7,53 & 42,88 & 14,29 \\
3 & BBNI & 35,00 & 35,00 & 25,20 & 95,20 & 31,73 \\
4 & BBRI & 45,41 & 40,36 & 30,27 & 116,04 & 38,68 \\
5 & BMRI & 45,00 & 45,00 & 30,00 & 120,00 & 40,00 \\
6 & INDF & 49,92 & 49,79 & 49,70 & 149,41 & 49,80 \\
7 & JSMR & 22,14 & 32,01 & 20,24 & 74,39 & 24,80 \\
8 & KLBF & 48,75 & 44,84 & 44,44 & 138,03 & 46,01 \\
9 & LSIP & 40,21 & 40,21 & 40,50 & 120,92 & 40,31 \\
10 & PJAA & 37,78 & 75,83 & 37,96 & 151,57 & 50,52 \\
11 & TLKM & 76,32 & 90,82 & 61,59 & 228,73 & 76,24 \\
12 & UNTR & 65,65 & 10,66 & 66,89 & 143,20 & 47,73 \\
13 & UNVR & 99,67 & 99,69 & 99,88 & 299,24 & 99,75 \\
14 & WIKA & 17,74 & 25,08 & 17,80 & 60,62 & 20,21 \\
15 & WSKT & 18,48 & 28,35 & 20,00 & 66,83 & 22,28 \\
\hline
\end{tabular}

Terdapat empat perusahaan yang mengalami peningkatan secara konsisten setiap tahun yaitu BBCA, BBRI, INDF dan KLBF. Terdapat dua perusahaan yang mengalami penurunan konstan setiap tahunnya yaitu pada perusahaan ASII dan UNVR. Rata-rata nilai dividend payout ratio tertinggi selama tahun 2015-2017 diperoleh oleh UNVR. Sementara rata-rata terendah diperoleh oleh perusahaan BBCA.

Tabel 4. Perkembangan DPS

\begin{tabular}{rlrrrrr} 
& \multicolumn{5}{c}{ Dividend per Share(Rp) } \\
\cline { 3 - 7 } No & $\begin{array}{c}\text { Kode } \\
\text { Saham }\end{array}$ & 2017 & \multicolumn{1}{c}{2016} & 2015 & Jumlah & $\begin{array}{c}\text { Rata- } \\
\text { rata }\end{array}$ \\
\hline 1 & ASII & 185,00 & 168,00 & 177,00 & 530,00 & 176,67 \\
2 & BBCA & 255,00 & 70,00 & 55,00 & 380,00 & 126,67 \\
3 & BBNI & 255,56 & 212,81 & 122,53 & 590,90 & 196,97 \\
4 & BBRI & 106,75 & 428,61 & 311,66 & 847,02 & 282,34 \\
5 & BMRI & 199,03 & 266,27 & 261,45 & 726,75 & 242,25 \\
6 & INDF & 237,00 & 235,00 & 168,00 & 640,00 & 213,33 \\
7 & JSMR & 60,63 & 78,09 & 43,13 & 181,85 & 60,62 \\
8 & KLBF & 25,00 & 22,00 & 19,00 & 66,00 & 22,00 \\
9 & LSIP & 45,00 & 35,00 & 37,00 & 117,00 & 39,00 \\
10 & PJAA & 52,00 & 62,00 & 69,00 & 183,00 & 61,00 \\
11 & TLKM & 167,66 & 156,14 & 94,64 & 418,44 & 139,48 \\
12 & UNTR & $1,303,00$ & 143,00 & 691,00 & $2.137,00$ & 712,33 \\
13 & UNVR & 915,00 & 835,00 & 766,00 & $2.516,00$ & 838,67 \\
14 & WIKA & 26,82 & 33,86 & 20,35 & 81,03 & 27,01 \\
15 & WSKT & 57,19 & 37,87 & 15,44 & 110,50 & 36,83 \\
\hline & & & & & & \\
\hline
\end{tabular}

Terdapat tujuh perusahaan yang mengalami peningkatan secara konsisten setiap tahun yaitu BBCA, BBNI, INDF, KLBF, TLKM, UNVR, dan WSKT. Perusahaan yang mengalami penurunan konstan setiap tahunnya yaitu pada perusahaan PJAA. Rata-rata nilai dividend per share tertinggi selama tahun 2015-2017 diperoleh oleh UNVR. Sementara rata-rata terendah diperoleh oleh perusahaan KLBF.

Tabel 5. Perkemabangan EPS

\begin{tabular}{rlrrrrr}
\hline & \multirow{6}{*}{ Kode } & \multicolumn{5}{c}{ Earning per Share (Rp) } \\
\cline { 3 - 7 } & Saham & 2017 & \multicolumn{1}{c}{2016} & \multicolumn{1}{c}{2015} & Jumlah & $\begin{array}{c}\text { Rata- } \\
\text { rata }\end{array}$ \\
\hline 1 & ASII & 466,39 & 374,37 & 357,28 & $1.198,04$ & 399,35 \\
2 & BBCA & 945,45 & 835,76 & 730,83 & $2.512,04$ & 837,35 \\
3 & BBNI & 730,16 & 608,02 & 486,18 & $1.824,36$ & 608,12 \\
4 & BBRI & 235,08 & $1.061,88$ & $1.029,53$ & $2.326,49$ & 775,50 \\
5 & BMRI & 442,28 & 591,71 & 871,50 & $1.905,49$ & 635,16 \\
6 & INDF & 474,75 & 472,02 & 338,02 & $1.284,79$ & 428,26 \\
7 & JSMR & 273,91 & 243,97 & 213,14 & 731,02 & 243,67 \\
8 & KLBF & 51,28 & 49,06 & 42,76 & 143,10 & 47,70 \\
9 & LSIP & 111,90 & 87,04 & 91,36 & 290,30 & 96,77 \\
10 & PJAA & 137,64 & 81,77 & 181,79 & 401,20 & 133,73 \\
11 & TLKM & 219,69 & 171,93 & 153,66 & 545,28 & 181,76 \\
12 & UNTR & $1.984,64$ & $1.341,03$ & $1.033,07$ & $4.358,74$ & $1.452,91$ \\
13 & UNVR & 918,03 & 837,57 & 766,95 & $2.522,55$ & 840,85 \\
14 & WIKA & 151,18 & 135,01 & 114,32 & 400,51 & 133,50 \\
15 & WSKT & 309,54 & 133,58 & 77,18 & 520,30 & 173,43 \\
\hline
\end{tabular}

Terdapat sebelas perusahaan yang mengalami peningkatan secara konsisten setiap tahun yaitu ASII, BBCA, BBNI, INDF, JSMR, KLBF, TLKM, UNTR, UNVR, WIKA, dan WSKT. Perusahaan yang mengalami penurunan konstan setiap tahunnya yaitu BMRI dan BBRI. Rata-rata Earning per Share tertinggi selama 
PENGAMBILAN KEPUTUSAN INVESTASI SAHAM MENGGUNAKAN PENDEKATAN

PRICE EARNING RATIO (STUDI KASUS PADA PERUSAHAAN TERDAFTAR DI

INDEKS SRI-KEHATI

PERIODE 2015 - 2017)

tahun 2015-2017 diperoleh oleh UNTR. Rata-rata terendah diperoleh oleh perusahaan KLBF.

Tabel 6. Perkembangan PER

\begin{tabular}{|c|c|c|c|c|c|c|}
\hline \multirow[b]{2}{*}{ No } & \multirow[b]{2}{*}{ Kode } & \multicolumn{5}{|c|}{ Price Earning Ratio (x) } \\
\hline & & 2017 & 2016 & 2015 & Jumlah & $\begin{array}{c}\text { Rata- } \\
\text { rata }\end{array}$ \\
\hline 1 & ASII & 17,80 & 22,28 & 16,79 & 56,87 & 18,96 \\
\hline 2 & BBCA & 23,16 & 18,95 & 18,02 & 60,13 & 20,04 \\
\hline 3 & BBNI & 13,56 & 10,01 & 10,16 & 33,73 & 11,24 \\
\hline 4 & BBRI & 15,48 & 11,40 & 10,99 & 37,87 & 12,62 \\
\hline 5 & BMRI & 18,09 & 16,86 & 10,51 & 45,46 & 15,15 \\
\hline 6 & INDF & 16,06 & 16,11 & 15,31 & 47,48 & 15,83 \\
\hline 7 & JSMR & 23,37 & 18,04 & 24,51 & 65,92 & 21,97 \\
\hline 8 & KLBF & 33,39 & 31,28 & 30,87 & 95,54 & 31,85 \\
\hline 9 & LSIP & 12,69 & 32,70 & 14,45 & 59,84 & 19,95 \\
\hline 10 & PJAA & 9,59 & 21,32 & 11,14 & 42,05 & 14,02 \\
\hline 11 & TLKM & 20,21 & 20,42 & 20,21 & 60,84 & 20,28 \\
\hline 12 & UNTR & 17,84 & 19,01 & 16,41 & 53,26 & 17,75 \\
\hline 13 & UNVR & 60,89 & 46,74 & 48,24 & 155,87 & 51,96 \\
\hline 14 & WIKA & 11,57 & 39,54 & 25,97 & 77,08 & 25,69 \\
\hline 15 & WSKT & 7,73 & 27,78 & 21,63 & 57,14 & 19,05 \\
\hline
\end{tabular}

peningkatan secara konsisten setiap tahun yaitu BBCA BBRI, BMRI dan KLBF. Tidak terdapat perusahaan yang mengalami penurunan secara konstan Rata-rata Price Earning Ratio tertinggi selama tahun 2015-2017 diperoleh oleh UNVR. Rata-rata terendah diperoleh oleh perusahaan BBNI. Semakin rendah nilai Price Earning Ratio maka harga saham tersebut semakin murah.

Tabel 7. Perbandingan Nilai Intrinsik dan Harga Pasar

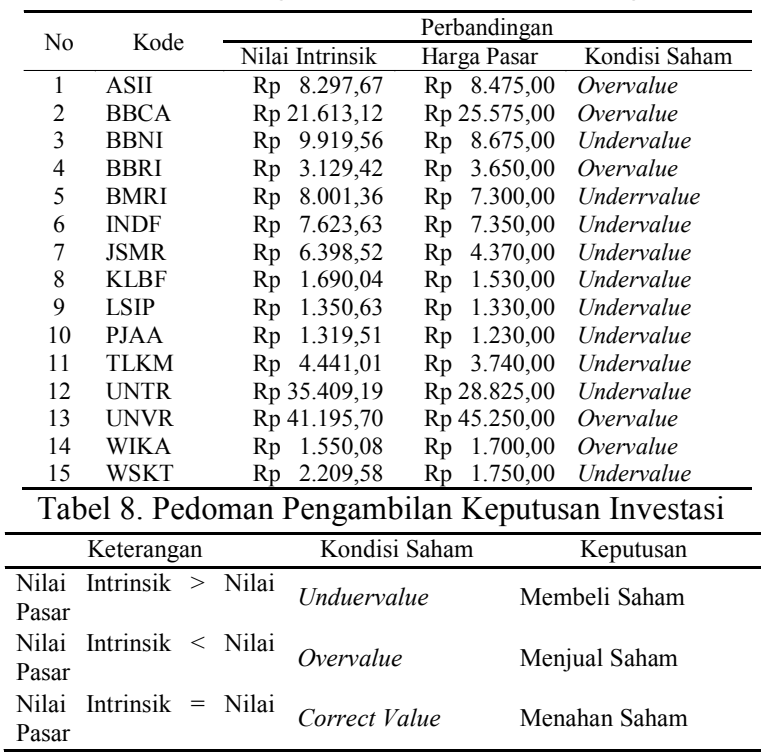

PENUTUP

Simpulan

Berdasarkan hasil perhitungan analisis pengambilan keputusan investasi saham menggunakan pendekatan Price Earning Ratio (PER) pada indeks SRI-KEHATI, dari 15 sampel perusahaan dapat diambil kesimpulan sebagai berikut :

1. Terdapat 10 perusahaan yang sahamnya dalam kondisi undervalue atau nilai intrinsik saham lebih besar daripada harga pasar, yaitu :

\begin{tabular}{cll}
\hline No & Kode Emiten & \multicolumn{1}{c}{ Nama Perusahaan } \\
\hline 1 & BBNI & Bank Negara Indonesia (Persero) Tbk \\
2 & BMRI & Bank Mandiri (Persero) Tbk \\
3 & INDF & Indofood Sukses Makmur Tbk \\
4 & JSMR & Jasa Marga (Persero) Tbk \\
5 & KLBF & Kalbe Farma Tbk \\
6 & LSIP & PP London Sumatra Indonesia (Persero) Tbk \\
7 & PJAA & Pembangunan Jaya Ancol Tbk \\
8 & TLKM & Telekomunikasi Indonesia (Persero) Tbk \\
9 & UNTR & United Tractor Tbk \\
10 & WSKT & Waskita Karya (Persero) Tbk \\
\hline
\end{tabular}

2. Terdapat 5 perusahaan yang sahamnya dalam kondisi overvalue atau nilai intrinsik saham lebih kecil daripada harga pasar, yaitu :

\begin{tabular}{cll}
\hline No & Kode Emiten & \multicolumn{1}{c}{ Nama Perusahaan } \\
\hline 1 & ASII & Astra Internasional Tbk \\
2 & BBCA & Bank Central Asia Tbk \\
3 & BBRI & Bank Rakyat Indonesia (Persero) Tbk \\
4 & UNVR & Unilever Indonesia Tbk \\
5 & WIKA & Wijaya Karya (Persero) Tbk \\
\hline
\end{tabular}

3. Tidak terdapat saham perusahaan pada indeks SRIKEHATI dalam kondisi correct value atau nilai intrinsik saham sama dengan harga pasar.

Saran

1. Bagi investor yang akan berinvestasi saham sebaiknya memilih saham dengan kondisi undervalue. Apabila telah memiliki saham dalam kondisi overvalue sebaiknya untuk dijual karena sewaktu-waktu dapat kembali ke nilai intrinsiknya. Jika tidak memiliki saham pada kondisi overvalue sebaiknya tidak melakukan transaksi pembelian saham tersebut.

2. Sebaiknya investor ketika akan melakukan investasi tidak hanya memakai satu jenis analisis saja tetapi juga menggunakan analisis yang lain dalam penilaian saham yaitu mengkombinasi antara analisis fundamental dengan analisis teknikal dan juga harus melihat serta mempertimbangkan faktorfaktor lain dari luar. Seperti faktor internal dan eksternal perusahaan yaitu melihat dari sisi perekonomian, perkembangan perusahaan, politik dan sebagainya.

3. Bagi peneliti selanjutnya, diharapkan dapat menambah dan memperpanjang periode penelitian agar dapat diperoleh hasil penelitian yang lebih baik dan akurat, peneliti selanjutnya juga dapat menambah jumlah sampel yang akan diteliti dan memilih populasi penelitian tidak hanya dikhususkan pada perusahaan yang ada pada Indeks SRI-KEHATI. 
PENGAMBILAN KEPUTUSAN INVESTASI SAHAM MENGGUNAKAN PENDEKATAN

PRICE EARNING RATIO (STUDI KASUS PADA PERUSAHAAN TERDAFTAR DI

INDEKS SRI-KEHATI

PERIODE 2015 - 2017)

\section{DAFTAR PUSTAKA}

Aganta, C,T., Topowijono, Z.A.,Zahroh,. 2015. Pengambilan Keputusan Investasi Saham Dengan Menggunakan Analisis Fundamental Melalui Pendekatan Price Earning Ratio(PER). Jurnal Administrasi Bisnis 27:3-4.

Bursa Efek Indonesia. 2018. Ringkasan Performa Perusahaan Tercatat. https://www.idx.co.id/datapasar/laporan-statistik/ringkasan-performaperusahaan-tercatat/. Diakses pada 28 Desember 2018 pukul 07.00 WIB.

Bringham, Eguene dan Joel F. Houdson. 2012. DasarDasar Manajemen Keuangan. Edisi Kedua. Jakarta: Salemba Empat.

Halim, A. 2015. Analisis Investasi di Aset Keuangan Edisi Pertama. Jakarta:Mitra Wacana

Hartono. 2010. Teori Portofolio dan Analisis Investasi. Edisi Ketujuh. BPFE. Yogyakarta.

Hermuningsih, S. 2012. Pengantar Pasar Modal Indonesia. Yogyakarta: UPP STIM YKPN.

Investing. 2018. Historical Data Indeks BISNIS27. https://www.investing.com/indices/bisnis27historical-data. diakses pada 15 November 2018 pukul 11.00 WIB

2018. Historical Data Indeks IHSG. https://www.investing.com/indices/jakarta-lq45historical-data. diakses pada 15 November 2018 pukul 11.10 WIB

. 2018. Historical Data Indeks Jakarta Islamic Index. $\quad h t t p s: / / w w w . i n v e s t i n g . c o m / i n d i c e s / i d x-$ islamic-historical-data. diakses pada 15 November 2018 pukul 11.15 WIB.

2018. Investing. 2018. Historical Data Indeks Kompass 100

https://www.investing.com/indices/kompas-100historical-data. diakses pada 15 November 2018 pukul 11.25 WIB

2018. Historical Data Indeks LQ45 https://www.investing.com/indices/jakarta-lq45historical-data. diakses pada 15 November 2018 pukul 11.45 WIB.

2018. Data Hisoris Indeks PEFINDO25. https://www.investing.com/indices/pefindo-25. diakses pada 20 November 2018 pukul 11.35 WIB
2018. Historical Data Indeks SRI-KEHATI https://www.investing.com/indices/sri-kehatihistorical-data. diakes pada 14 November 2018 pukul 10.00 WIB.

2018. Kenapa Bandar Suka Buat Sahamnya ARA, \& Bursa Tidak?! https://id.investing.com/analysis/kenapa-bandarsuka-buat-sahamnya-ara--bursa-tidak--200205138. diakses pada 18 November 2018 Pukul 21.00 WIB.

Jones, P. Charles. 2009. Investment Analysis and Management. New York: John Whiley and Sins Ms.

Kehati. 2017. Mengenal Indeks SRI-KEHATI. http://kehati.or.id/mengenal-indeks-sri-kehati/. diakses pada 19 November 2018 pukul 08.30 WIB

Tambunan, Andy porman. 2007. Menilai harga Wajar Saham (stock valuation). Jakarta : PT. Elek Media Komputindo.

Tandelilin, E. 2010. Portofolio dan Investasi: Teori dan Aplikasi. Edisi Pertama. Yogyakarta: Penerbit Kanisius.

Wulandari, O, S., Rahayu, S, M., Nuzula, N, F. 2016. Analisis Fundamental Menggunakan Pendekatan Price Earnings Ratio Untuk Menilai Harga Intrinsik Saham Untuk Pengambilan Keputusan Investasi Saham(Studi pada perusahaan yang sahamnya masuk indeks LQ45 Periode tahun 2010-2012 di Bursa Efek Indonesia). Jurnal Administrasi Bisnis 23:74. 